\title{
2. The River, the Water and the Crocodile in Marovo Lagoon
}

\section{EDVARD HVIIING}

\section{Introduction}

In this chapter, I examine the interrelationships between salt and fresh water-ocean, lagoon and rivers-and land in the Marovo Lagoon area of the western Solomon Islands, based on my fieldwork there since 1986. The account is primarily an ethnographically descriptive one, grounded in what, during my first period of fieldwork in Marovo Lagoon (18 months, 1986-87), was a consistent immersion in everyday subsistence practice, involving daily participatory engagement with the environments of sea and land through fishing, gathering, hunting and gardening, and regular navigation of my own canoes around the lagoon and the rest of the New Georgia group of islands, of which the Marovo area forms the eastern part (Hviding 1996; see Figure 2.1). While I shall provide a general account of the cosmological foundations for the organisation of environmental and symbolic realms in New Georgia, in order to outline relationships between sea, land and river, I turn to the experience of everyday practice for ethnographic insights into how the people of Marovo Lagoon engage with their environments and the creatures they contain. In this regard, it is interesting that the relationships between people and fresh water, between land and river-so prominent until the late nineteenth century but later becoming less significant-have seen recent intensification through the environmental problems caused in the lagoon by large-scale logging 
operations on the land (carried out by Asian companies across New Georgia, in quite destructive fashion) and through the rapid proliferation of piped water supplies to villages.

Since the early twentieth century, just about all villages in New Georgia have been located in coastal areas, after demographic upheavals and transformations of political economy caused inland settlements and associated large-scale irrigated taro cultivation to be gradually abandoned (Hviding and Bayliss-Smith 2000: 145-52; Bayliss-Smith et al. 2003). The demographic pattern shown on present-day maps is, then, a historically specific configuration very different from that of pre-colonial times. Until the late nineteenth century, the flow of river water as a foundation for surplus-generating irrigation was central to the regional political dynamics of New Georgia. On this background, rivers are today repositories of complex inland histories, and river travel by those whose ancestral generations lived and cultivated in the interior lands of New Georgia can be a powerful statement about the longevity of territorial claims.

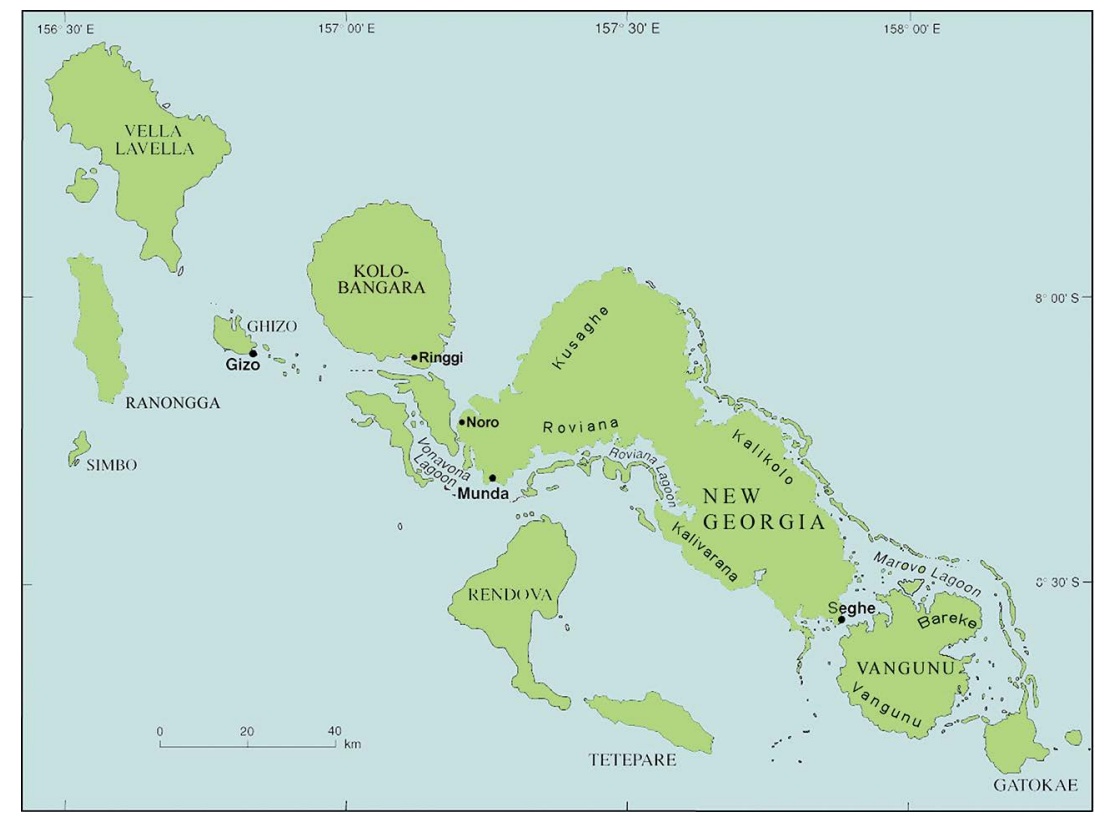

Figure 2.1 New Georgia and associated islands and lagoons.

Source: University of Bergen. 
I shall approach river and water from a grounding in an inclusive sociality that, in everyday practice, connects human and non-human agents and domains on many levels of meaning. Building my discussion of water and rivers from an experience-based view of Melanesian social life, I take as my starting point some basic distinctions in the Marovo view of the lived, and living, world.

\section{Sea, River, Territory: Templates of Existence in Marovo}

In the Marovo language, salt and fresh water are clearly distinguished as idere and kavo respectively. Interestingly, while idere means sea or salt water, it also refers to fresh water that is hot (i.e. heated); whereas kavo, beyond being a generic term for fresh (drinkable) water, also refers to those major water courses classifiable as rivers. I shall build on this quite pliable distinction to provide some introductory ethnographic glimpses, first focusing on some key non-human species that have iconic value for the distinction.

It should come as no surprise that, in seaboard Melanesia, the most significant animal representatives of sea and river are two formidable predators that can be more than a match for the humans who encounter them: sharks (kiso) and crocodiles (vua). Since these predators have such potential to profoundly affect human existence, they are deeply tied into vernacular socialities through ancient association with specific kin groups whose members have, over the generations, engaged with sharks and crocodiles in their respective environments. At base, this has existential foundations in a historical distinction throughout the Marovo area (as in many other parts of island Melanesia) between 'bush people' and 'saltwater people', whereby the former have associations with the crocodile and the latter with the shark. Interestingly, the everyday habits of crocodiles to some degree mirror the historical pattern of everyday life among bush people, in terms of moving regularly between the inner lands and the coasts. And so, the specific environmental realm of rivers, connecting as it does the inner lands and the sea, is inextricably tied to the movements of that fearsome predator, the saltwater or estuarine crocodile (Crocodylus porosus). Conversely, the saltwater people's associations with sharks mirror the predatory maritime warfare that characterised the pre-colonial lives of those kin groups; the shark roams and ranges wide and far-in the lagoon, but also far beyond and 'up' to the open ocean. 
The extraordinarily close maritime engagements of Marovo people (though mainly men) allow for detailed knowledge of many locally named species of sharks. A recent overview (Hviding 2005: 29-31) indicates that Marovo shark classification includes 15 or more vernacular taxa. However, the totemic traditions in question depart from such precise knowledge to focus simply on a generic, predatory ancestral shark that eats people (preferably enemies) and that moves freely, near and far, in maritime space, using the prominent topographic feature of passages through the barrier reef as its conduit between lagoon and ocean. In the Marovo scheme of spatial directions, the ancestral sharks move on a horizontal plane, in and out from open sea and lagoon. Unlike this open-ended mobility of the generic ancestral shark, the crocodile, of which there are only two Marovo taxa (one of which is that referred to in ancestral totemic traditions), maintains a shuttling behaviour back and forth along river courses, conceptualised in spatial schemes as vertical: down through estuaries into the lagoon and, from there, even all the way $u p$ to the barrier reef. These important cosmological foundations involving the shark and the crocodile amount to close descriptive accounts of the environmental dynamics of flow concerning sea and river.

The cyclical dynamics — tidal, lunar, seasonal—of the sea are elaborated in the Marovo concept of kolokolo ('time'), which is a reduplication of kolo ('ocean'). The notion of time itself thus appears to be modelled on a combination of oceanographic processes and human activities that are at once predictable, yet erratic, and observable, yet eternal and open-ended. Conversely, the river is a prime linear mover of land-sea relationships, both social and environmental. Although the tides flow and ebb in estuaries, and rivers may at high tide have salty surface water quite far inland, it is the powerful, insisting, unidirectional downwards movement of water from the inner lands to the sea that is the defining characteristic of rivers. I am going to discuss a range of past and present situations and contexts, generic and specific, in which this particular quality of rivers is at the forefront in Marovo and New Georgia more widely. While I rely on the Marovo language for vernacular concepts, I emphasise that those concepts from Marovo generally have cognates throughout the Austronesian languages of New Georgia, and my discussion is therefore of regional scale.

I have elsewhere analysed at length the everyday practice of saltwater people and the many dimensions of relationships in Marovo between people and sea (Hviding 1996), but the river as such is a long overdue focus in my writing and analysis concerning the western Solomons. 
Hence, I now bring attention to the large rivers of the high volcanic island of New Georgia and its eastern neighbour Vangunu. These islands are two big, mountainous land masses extending from the northwest to the southeast for about $100 \mathrm{~km}$, with the raised barrier reefs that define the large lagoons of Marovo and Roviana enclosing the northeastern and southwestern coasts of New Georgia, and the northern and eastern coasts of Vangunu (see Figures 2.1 and 2.2). The sheltered, island-dotted lagoons extending between the mainland coast and barrier reef islands are the central focus of the maritime lifestyle of the New Georgia people, who are renowned experts in fishing and marine gathering. With very few exceptions, villages of the present time are all in coastal locations, some on small low islands in the lagoon, or on the raised barrier reef itself.

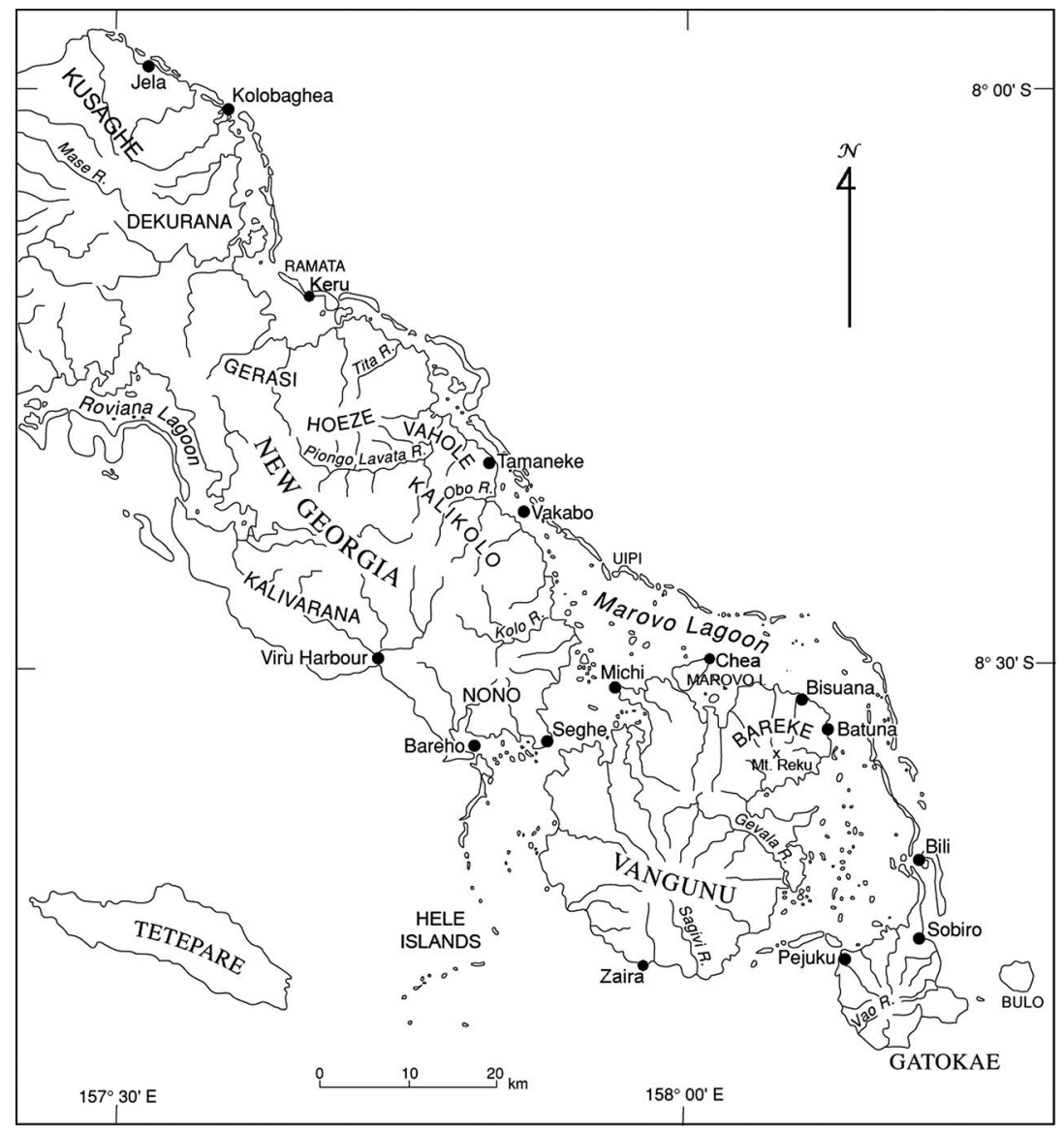

Figure 2.2 Marovo Lagoon, showing rivers and place names.

Source: University of Bergen. 
Transitional ecological zones give their own, particularly significant contributions to the resilient subsistence economy of the more than 30,000 villagers of the New Georgia Islands. While the ocean-facing reef walls of the barrier islands provide rich fishing grounds (particularly for underwater spearfishing), the extensive mangrove swamps that fringe the mainland coasts (and some lagoon-facing coasts of barrier islands) offer stocks of bivalve Polymesoda molluscs and mud crabs (Scylla serrata). As in many parts of the island Pacific, the fundamental New Georgian meal consists of some protein in the form of fish or shellfish, with the main ingredient being root crop staples and leafy vegetables obtained from shifting cultivation in the lower foothills behind the coastal village locations. But land and sea are interconnected realms in more than economic and culinary senses; they form an interrelated continuum in the pervasive Marovo concept of puava, a territory conceptualised much like the vanua of Fiji and the abupua'a of Hawai' $\mathrm{i}$, which ranges over a succession of ecological zones and is inhabited by the people who control it as their ancestral estate. The puava (referred to in other New Georgian languages by cognates such as pepeso, pepeha, etc.) is a cosmological foundation whereby social group and territory are mutually constituted, and is additionally significant in the New Georgian context of bilateral kinship, where it is shared belonging to, and engagement with, a named puava that defines the kin group (Hviding 2003a).

At its greatest conceptualised extent, a particular named puava, held collectively as ancestral estate by the recognised members of a homonymous cognatic kin group referred to as a butubutu, may extend from the mountain tops and high-elevation ridges in the interior, through mountain slopes, foothills and lowland basins to the mangrove-fringed coast, across the lagoon, out to and including the barrier reef. This pattern characterises the puava of 'mixed' butubutu that have formed historically from amalgamations of bush and saltwater groups, and as such are simultaneously coastal and bush (as well as river) people (see Wagner, this volume). It should be noted here that quantification of land-holding and sea-holding butubutu throughout the Marovo area is not a straightforward matter, owing to bilateral kinship and the consequent multiplicity of social relations, coupled with historical upheavals. A cautious estimate would imply about a third of the recently significant kin groups in each of the saltwater, bush and mixed categories, though with a somewhat smaller demographic proportion for saltwater groups (Hviding 1996: 377-81). As a result, most butubutu do remain of saltwater or bush orientation, 
and their puava include either coastal fringes with large areas of lagoon and barrier reef, and islands therein, or vast tracts of land extending from interior mountain tops all the way down to the lagoon shore. The rivers that are such prominent features, indeed makers, of the landscape (and seascape) are thus mainly under the control of butubutu considered to be of bush orientation and, in a very important sense, remain mediating zones between the domains of bush and saltwater groups.

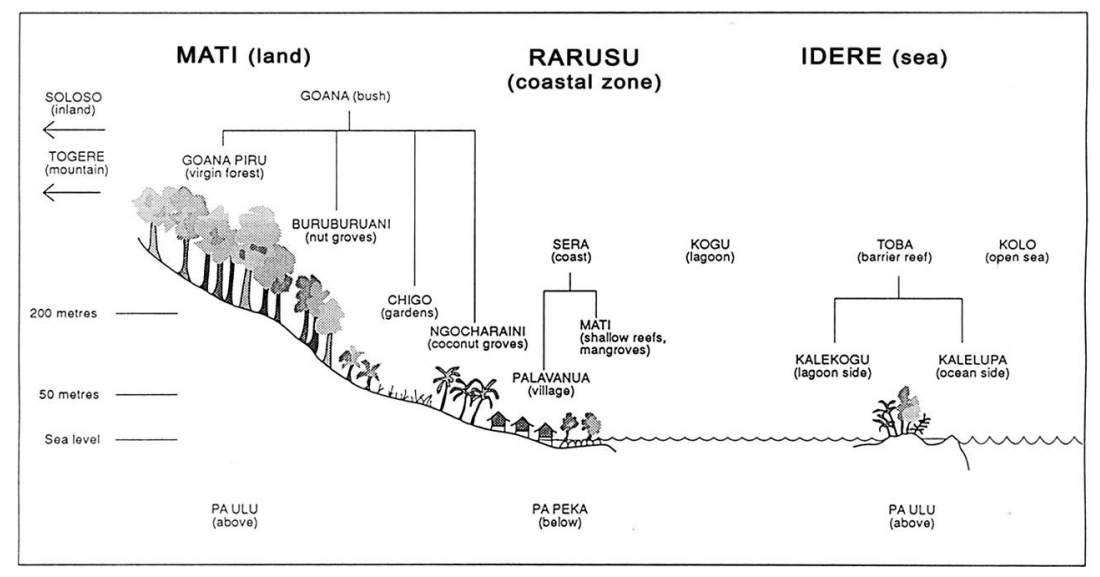

Figure 2.3 Cross-section diagram of the Marovo puava.

Source: University of Bergen.

Let me now expand the interpretive dimension of the concept of puava in order to note that it is fundamentally the word for 'earth', but, in its wider territorial reference frame, applies to all that which is owned by a butubutu as ancestral title, including land, rivers, reefs, lagoon islands and sea (see Figure 2.3). Some butubutu of the coast or of salt water, then, have mainly lagoon and reefs as their holdings, whereas other butubutu of the bush control large tracts of land on the high islands. According to a foundational environmental classification scheme that applies to the domain of the wild (piru), and takes priority over the more domesticated puava concept that has the inhabited seashore as its central focus, Marovo people conceptualise and speak of the distinction between mati (dry land) and idere (sea, salt water), with rarusu (coast) as an intermediate zone subject to tidal influences. At their outer perimeters, both mati and idere are wild, in that interior lands and watercourses, as well as outer reefs and the ocean, are beyond the central domesticated (manavasa) zones of the puava that cover the lower cultivated foothills, the inhabited or cultivated coast, and the lagoon. The domesticated zones are located 
'below' ( $p a$ peka) in relation to the wild zones 'above' ( $p a$ ulu). In this sense, rivers and fresh water (kavo) are integral to the overall zone of mati and, in their spatial extent, cross-cut the topographies of the wild and the domesticated. On a more specific level, rivers form a distinct water domain from that of the sea. The distinctiveness of this opposition, as well as the cultural divide between people of the sea and of the bush, remains today, despite universal coastal settlement.

\section{River Stories, Past and Present}

The large mountainous islands of the New Georgia group have rugged volcanic landscapes that include extinct craters with towering rims, deep valleys, pinnacles of raised limestone and tall peaks, rising in places to over $1,000 \mathrm{~m}$. Clouds characteristically hover in the New Georgia mountains and, while weather at the coast and in foothills has a microclimate with significant seasonal variation, rainfall at higher altitudes is much more regular. According to estimates provided by the Solomon Islands' meteorological services, annual rainfall in places such as the crater summit of central Vangunu, where elevations exceed 1,000 m, may approach $9,000 \mathrm{~mm}$. Massive interior rainfall feeds the headwaters of a great number of rivers in the New Georgia and Vangunu mountains. Through stony shallow rapids, slow-flowing meanders and countless streams and small tributaries, water is channelled by the volcanic topography into the major rivers that wind their way through deep valleys and low-lying swamp basins towards expansive mangrove-fringed estuaries, thereby providing the ecological and cosmological connection between the land and the sea. Since all is subsumed in the puava concept, the rivers, in an important sense, cross-cut the generic puava, provide convenient and unambiguous political boundaries between specific named (and owned) puava, and have a reach of environmental influence across the lagoon all the way to the barrier reefs and, ultimately, into the open ocean.

Since my specific geographic focus is the eastern part of New Georgia referred to as the Marovo Lagoon, a closer explanation of the area's quite unique topography is needed. The vast reef-and-lagoon sea spaces of Marovo cover around $700 \mathrm{~km}^{2}$. A raised barrier reef extends for about $100 \mathrm{~km}$ from the northwestern to the southeastern entrances to the lagoon, running parallel to New Georgia and Vangunu and terminating at the northern tip of the high island of Gatokae. The Marovo barrier reef takes the form mostly of long, narrow and twisted raised islands covered 
in a particular botanical configuration of lowland rainforest in many places fringed by mangroves. Two-thirds of the barrier reef that forms the Marovo Lagoon follow the northern coast of New Georgia, mostly at distances between 1 and $2 \mathrm{~km}$ from the mainland coast; however, at the southeastern end of New Georgia, the width of the lagoon increases to more than $8 \mathrm{~km}$, ultimately forming a globally unique double barrier reef along the lagoon's eastern perimeter. A subsidiary raised barrier reef extends between Gatokae and the southeastern tip of Vangunu, almost enclosing the vast lagoon.

Throughout its extent from north New Georgia to Gatokae, the raised barrier reef is intersected by more than 20 open passages (sangava) from lagoon to ocean. Most are fairly deep and navigable, but some are shallow with sandy reef flats and small islets. The passages by the ocean provide a particular connection to the volcanic topography at the other side of the lagoon. In fact, a closer look at a map (e.g. Figure 2.2) shows that all major deep passages are spatially aligned with the estuaries of major rivers on the high volcanic islands. This reflects a long-term environmental process whereby freshwater influences from the rivers have inhibited the formation of coral in those areas where river currents flow towards and meet the barrier reef. Quite simply, the barrier reef passages have been made by the rivers. Several folk tales of New Georgia metaphorically invoke the forces of rivers in the creation of passages through the barrier reef in the form of powerful crocodiles, legendary beings of particular named rivers that have had reason to cut through barrier islands to create openings to the ocean (e.g. Hviding 1995: 74-80). Another important social and cultural manifestation of the topographical singularity of river-passage correspondence is that marine boundaries between puava are conceptualised as invisible lines extending across the lagoon from mainland rivers to the adjacent barrier reef passages.

Nevertheless, while great stories are told and complex narratives can be constructed about the land and sea of Marovo, the rivers have received less attention, whether in terms of oral traditions, academic studies or international conservation efforts - the latter having been a major scene of contestation in the Marovo Lagoon since the 1990s (Hviding 2003b, 2006). This lack of attention belies the long and complex cultural histories of rivers, highlighted by the past role of their upper reaches as water sources for large-scale irrigated taro cultivation in pond fields called ruta (see Bayliss-Smith and Hviding 2012, 2015), by traditions that tell of bush people with no access to canoes using the river banks as fast 
access routes between inland settlements and coastal locations, and by recent conflict between butubutu of bush and saltwater orientation over logging and associated river-carried sediments. The latter is a particularly contentious present issue.

There are indications that the geological characteristics and scale of ecological systems in New Georgia have always allowed large rivers to carry sediments into the sea. For example, in 1893, Commander A.F. Balfour of the Royal Navy, whose ship the HMS Penguin was engaged in an extensive hydrographic survey of the New Georgia group, examined the wide, almost landlocked bay known as Viru Harbour on New Georgia's south coast. Having taken the large ship in by steam through the narrow entrance and anchored in deep water, he noted that the bottom of the bay was covered in black mud, surmising that there had to be 'a river somewhere as the surface water is fresh and very much discoloured. The anchorage is very small but good the bottom is coral with a deposit of [b]lack mud on the top ...' (Balfour n.d., entry for 3-4 November 1893).

With a narrow passage to the ocean, Viru Harbour is obviously vulnerable to sedimentation, and the black mud observed from the Penguin had been deposited in the deep bay by no less than three major rivers emerging from the volcanic hills. This strong terrestrial connection of the deep landlocked embayment has been perceived as the main reason for siltation during a long period of logging operations from the 1960s onwards, but, as evident from Balfour's notes, the harbour already had a mud-covered bottom and discoloured water in 1893 .

While river-carried sediments may always have been a feature of the lagoon environments around New Georgia, the scale of deposits and density of silting has increased in many areas, as logging operations since the 1980s have created deforestation and soil erosion in most of the foothills of New Georgia, Vangunu and Gatokae (Hviding and BaylissSmith 2000; see Figure 2.4). The most recent impact of this post-colonial environmental entanglement was the sudden large-scale death in 2011 of marine organisms (from molluscs to dolphins) over much of the central part of Marovo Lagoon, caused by an algal bloom from heavily silted inshore areas (Albert et al. 2012). This disaster caused angry reactions from groups of saltwater people who live on small islands and have customary tenure over most of the lagoon and barrier reef, but who own little land and, thus, unlike the bush people (who receive timber royalties from logging companies), reap few financial benefits from logging. The twenty-first-century relationship between land and sea, now emerging 
as a matter of political ecology in terms of the river carrying destructive effluent into the sea, is set to intensify throughout Marovo, and to generate more acrimonious conflict between land-holding and sea-holding kinship groups as logging operations continue to expand. Figure 2.4 shows impacts on the land and lagoon of logging operations in the hills, with river-carried sedimentation from the estuary at the lower left of the image. Across the lagoon, the forested barrier reef islands are visible in the upper right-hand corner.

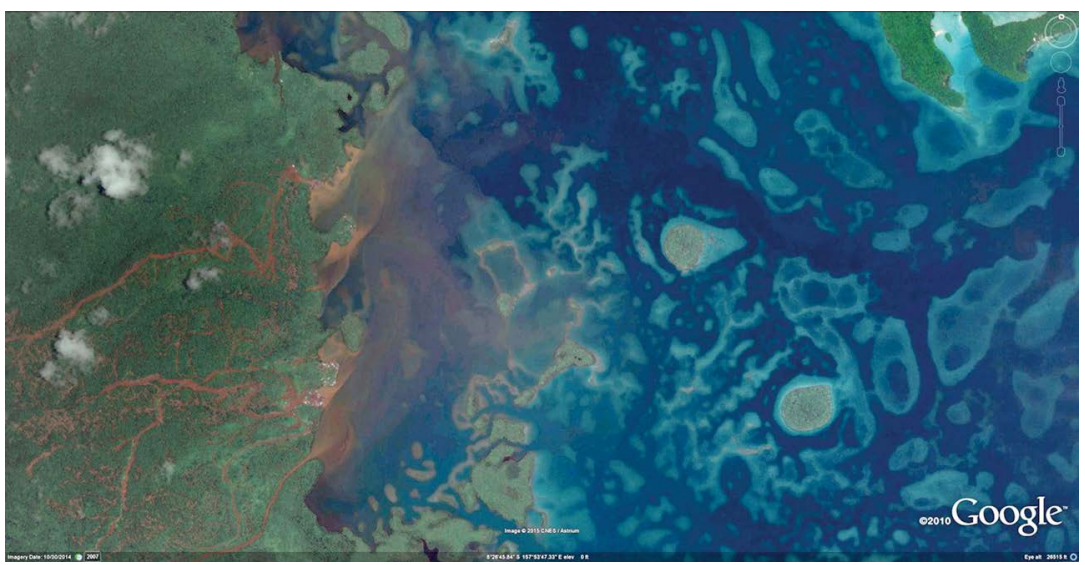

Figure 2.4 Satellite image of the Kolo River area in the western central part of Marovo Lagoon.

Source: Google Earth, October 2014.

Some historical glimpses of rivers as scenes and contexts of human practice are in order here. For the bush people of old Marovo, the lower reaches of major rivers were fishing grounds where hand spears and bow and arrow were the chosen technologies. According to traditions, the bush people rarely possessed canoes, and so no fast water transport between inland and coast was possible for them. However, the banks of streams and rivers provided paths along which bush people could move to the coast and back, sometimes to carry out food exchanges with the saltwater people, who, outside of regular barter occasions, were their enemies and likely to procure slaves and heads from the inland. The act of walking down from hillside settlements, following routes along streams and rivers and arriving at the seashore, is referred to in Marovo as horevura ('descend-and-emerge'). This term is also used to refer to the ultimate mass migrations that took place between 1890 and 1920, bringing bush people down to the seashore for permanent settlement once headhunting and intra-Marovo warfare had ceased (Hviding 1996: 97-9). 
Long before this process of permanent horevura, however, men from the bush would use streams, rivers and tidal creeks and swamps as scenes for productive activity to supply their hillside households with fish, molluscs and crustaceans-much-desired food that is not available in the forest. The main rivers and their adjacent watercourses and flooded lands were used to good effect, providing not only fish and shellfish, but also sheltering the fishermen from the view of the saltwater people, as illustrated by this tale from the hills of Bareke in central Marovo:

There was a family of a mother and five children. The four brothers made bows. They made arrows to shoot fish. One day, those four went down through the bush from the mountain above Seke in order to descend and emerge near the point at Seke. As those four brothers walked along the Eleluku stream, they continued fishing until they came out at the mouth of the big river Kolo. Then they carried strings with fish back uphill, to their mother and sister who stayed behind in the village. (Adapted from Hviding 1995: 49)

Wisely, the four brothers turn back the moment they reach the open landscape of a major estuary, as to 'come out' in this context means 'to emerge into view'.

Lieutenant H.B.T. Somerville of the aforementioned HMS Penguin spent several months ashore in coastal villages of Marovo during 1893-95, using these locations as a base from which to survey the lagoon with a small steamboat and a handful of seamen. Somerville did more than hydrography and chart-making, however. He had a copy of the Royal Anthropological Institute's 'field manual', Notes and Queries on Anthropology (Garson and Read 1892), and, like quite a few other gentleman travellers of the day, he engaged in some solid proto-anthropology, ultimately publishing his findings in a 60-page article in the Journal of the Royal Anthropological Institute (1897). In his account of the relationships between the lives and political domains of the inhabitants of the Marovo Lagoon, he noted the following about the local people, who at the time still had a particular reputation for 'savagery':

Their general demeanour is by most white people said to be 'ferocious', and certainly they are inveterate head-hunters. Our officers, however, never experienced anything but civility, good temper, and occasionally kindness at their hands. The result of their custom of head-hunting has been to drive a certain proportion of 'salt water' folk back into the interior, where the tropical density of the bush, and maze of tracks, ensure their safety. I have no doubt that this habit, continued from time immemorial, 
has given rise to an opinion (derived from contempt of a foe who hides, rather than fight for his head) that 'man-bush' belongs to a different, and insignificant race. One short excursion that I made into the interior apprised me of the fact that part of the [New Georgia] group, anyway, instead of being very sparsely populated in a few villages on the coast, as generally supposed, is, on the contrary, fairly well inhabited in the interior slopes and valleys of the hills where, in quite a small radius, huts and clearings appeared on all sides in the midst of the bush; quite invisible, however, to a passing ship or canoe. (Somerville 1897: 358)

This, then, was the situation at hand before the process of horevura began, and, as already indicated, the divisions remain-although all Marovo villages are now on the coast. I have spent most of my threeand-a-half years of fieldwork in Marovo living with the descendants of Somerville's 'inveterate head-hunters'. This has given me a special vantage point from which to explore the rivers of the rugged mountainous mainland that forms the dark, often cloud-covered backdrop to the beach locations of the saltwater people. Quite simply, saltwater people tend to dislike rivers. They perceive, and treat, mainland rivers as a spatial domain distinctively opposed to the sea and, to some degree, a hostile realm to them. Predictably, and from my subjective point of view as an anthropologist in Marovo raised by them as a saltwater man, after 30 years of regular visits I still have not come fully to terms with the dark, muddy domain of the large rivers of New Georgia and the strange and dangerous creatures there. I still find those rivers to be fascinating, exotic and somewhat frightening worlds. This has only partly been remedied by the many shorter stays I have had in the bush village of Tamaneke in northern Marovo, which is itself located in an estuary.

While everyday life and travel on the lagoon coast and out at sea is dominated by a wide open sky, endlessly bright and sometimes harsh and glaring sunshine, and cooling (sometimes even cold) gusty winds, human movement in the domain of rivers is dominated by the dark verdant galleries of estuarine mangroves and riverbank forests, a partly obscured sky and often bursts of torrential rain, particularly in the upper reaches of rivers closer to the inner lands. From the bright and windy world of the sea, one enters the shady and calm world of the river, which may at times even provide sheltered refuge for sea travellers caught in a squall. Even saltwater men dedicated to maritime practice at times admit that the coolness of a large river can provide a pleasant alternative to the scorching heat on the lagoon and the ocean. While rivers and fresh water are cold 
(manobu), the sea and salt water are warm (reka). While coldness is not generally desired, it can be so for situational comfort or, most notably, for medical purposes, since some rivers of Marovo have a reputation for having water with strong healing powers in their upper, shallow and fasterflowing reaches. Even reluctant saltwater people may seek out such places when disease necessitates it, courtesy of the knowledge and guidance of their bush neighbours or in-laws.

\section{Piongo Lavata: Travelling the Great River}

In the Kalikolo district in the northern reaches of the Marovo Lagoon, canoes powered by outboard motors can reach extraordinarily far inland along major rivers such as the mighty Piongo Lavata. ${ }^{1}$ The huge water system of Piongo Lavata meanders up from the coast through a great basin of flat swampland for almost 15 navigable kilometres, with a great number of tributary creeks, streams and swamps intersecting the tall galleries of riverside vegetation. Throughout my fieldwork, I have lived for shorter periods in the central Kalikolo village of Tamaneke, and the bush people of the Vahole butubutu, who have been my hosts there, have humorously and generously taught me, in my stereotypical capacity as a saltwater man with little fondness for rivers, how to travel in, and even to some degree appreciate, the dark, muddy and imposing world of their big waterways. The Vahole people number only about 400, but their puava is one of the largest in all of New Georgia and, from barrier reef to mountain peaks, covers an area of more than $200 \mathrm{~km}^{2}$. The Piongo Lavata is the heartland of their huge puava, and their ancestral history is enshrined in the river and its surrounding forests.

Behind the mangrove maze and changeable mud flats of the estuary, the Piongo Lavata's muddy banks are obscured by dense stands of mangroves in the wide tidal zone and of nipa palm just further up. The brackish swamps that extend here on both sides are a zone for extensive food gathering, mainly by women, and offer huge stocks of mud crab and Polymesoda and Anadara bivalves. In the true freshwater zone that follows, tidal influences are less significant. The distinctive hyper-organic smells of mangroves give way to the earthy sensory impressions of true river mud and of fragrant riverside leaves and flowers. The river banks become more

1 The name means 'Great River' in the Hoava language spoken in Kalikolo. 
exposed, and here and there one finds easy access to locations known for the presence of large freshwater eels in underwater burrows along the riverbank. It is in the lower reaches of the freshwater zone, away from the mangroves where the forest galleries are at their tallest, that substantial clearings have been made in recent years, both by logging operations (mainly preoccupied with stands of the huge freshwater swamp tree Terminalia brassii) and by a proliferation of new food gardens along the river banks where the soil is extraordinarily fertile (Figure 2.5). These garden lands are, on at least an annual basis, flooded by water carrying nutritious sediments. Some say that with the intensification of logging in the foothills, in many cases very close to river tributaries, the flooding of the Piongo Lavata has become more frequent.

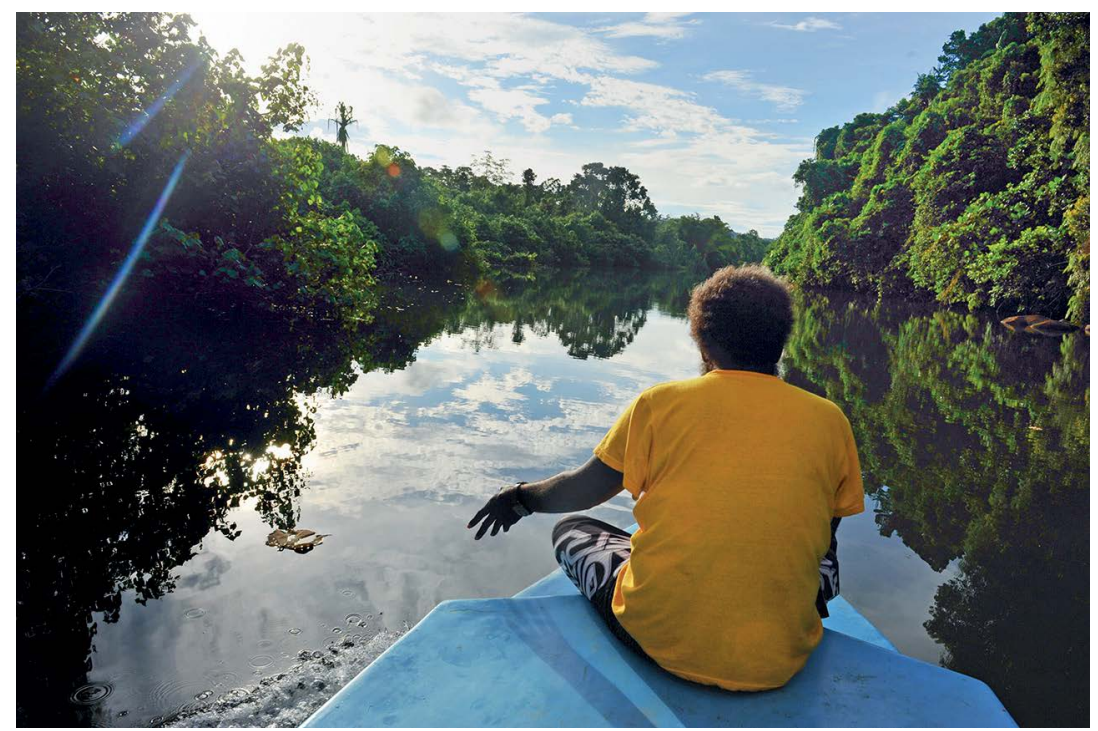

Figure 2.5 Navigating the lower middle reaches of the Piongo Lavata River.

Source: Photo by the author, 2012.

Further up (although this may still be not much above sea level, since most of New Georgia's major rivers only rise quickly through rapids quite far inland), the river traveller is enveloped by dark verdant forest, which, as one gets higher, increasingly forms a rather closed canopy and shuts out the light (Figure 2.6). Noises made by great flocks of parrots reverberate in this confined space, and any sound, such as the movement of a paddle in the water and along the side of a canoe, seems to be amplified and echoed. But this is still a domain of deep cultural history. Even the largely intact 
riverside forest further inland contains, for the initiated eye, many signs of the dense settlement and cultivation of these extensive lowlands in the past. Groves of Areca (betel nut) palms, or tell-tale secondary forest trees and shrubs, which at both canopy and ground levels provide evidence of past vegetation clearance, all point to the density of interior settlement in the past. In this remote part of Marovo, people lived inland for much longer than in the central lagoon area. The Vahole people were masters of ruta (irrigated terraced taro cultivation) and, into the twenty-first century, some small irrigated taro plots were still being cultivated along tributary creeks of the Piongo Lavata. Today, the special pond field types of Colocasia taro, called talo ruta, are still present in the middle freshwater reaches of the Piongo Lavata. Some have been planted secretively for safekeeping of the species, but talo ruta increasingly betrays this purpose by going feral and turning up in riverside locations, reminding observant passers-by of the history of inland settlement and cultivation (Figure 2.7). The criss-crossing of the riverside landscapes by signs of past habitation and cultivation, often in the form of sites associated with named ancestral persons, is a powerful demonstration of customary entitlements to the Vahole land.

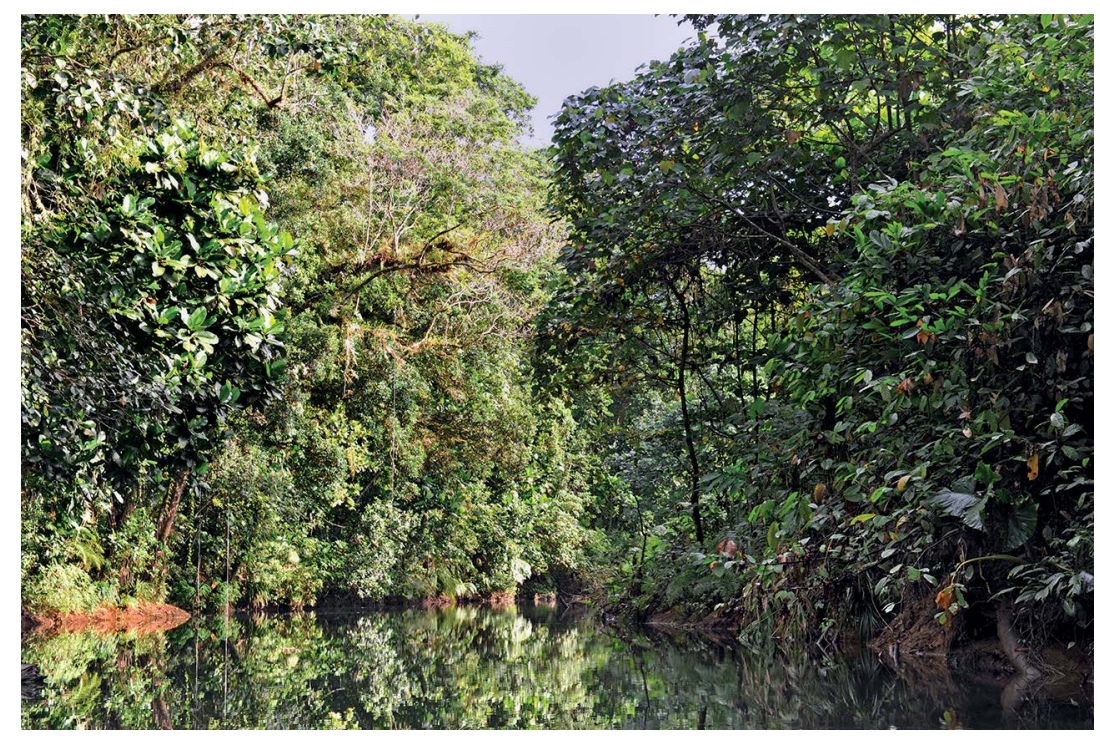

Figure 2.6 Largely undisturbed river forest in the upper middle reaches of the Piongo Lavata River.

Source: Photo by the author, 2012. 


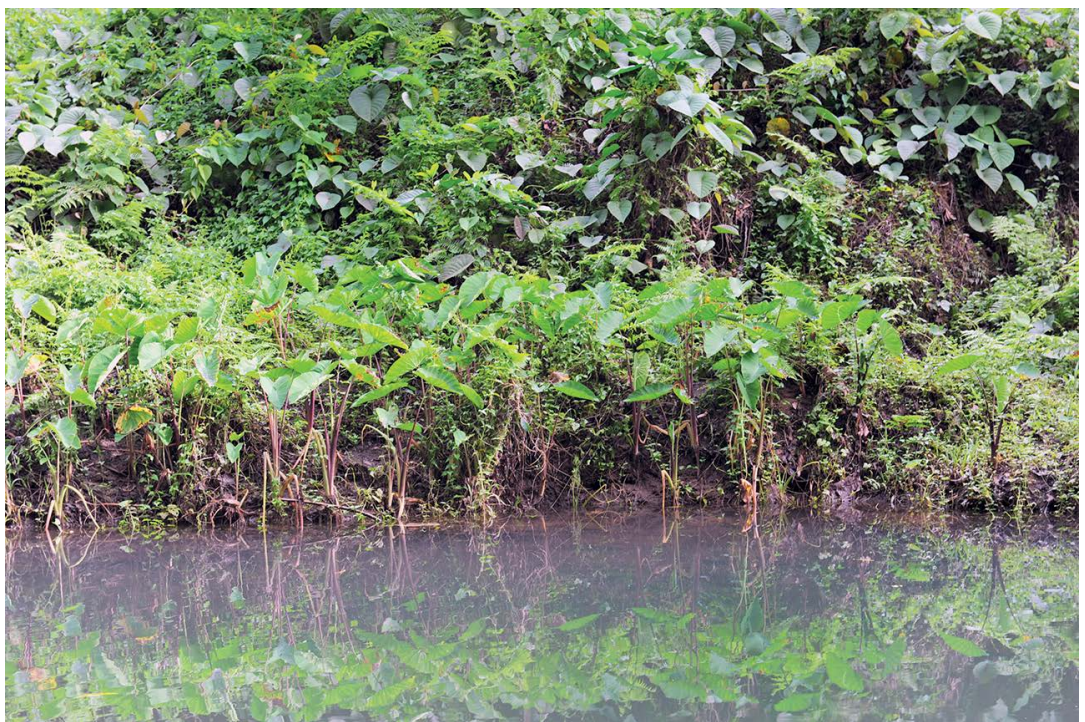

Figure 2.7 Wetland pond field variety of Colocasia taro in feral state.

Source: Photo by the author, 2012.

This far up the river, broken branches stuck on the bottom and volcanic boulders in the water are hurdles to navigation, but, as the water gets less turbid, its clarity allows for an easier view of such underwater obstructions. Given today's proliferation of crocodiles, this zone of clear water flowing with increasing speed over a sandy riverbed (Figure 2.8) is the only place in the river where people will relax their continuous alert for the predators. Crocodiles have, in recent years, made quite regular attacks on women working in their riverside gardens in the lower middle reaches of the river. Those who have survived have, in most cases, lost an arm, since the crocodile tends to attack women as they wash the day's harvest of root crops by the river bank. In the upper middle reaches, crocodiles are not infrequently seen resting on logs and mud flats along the river banks. But nearer to the rapids it is a different matter. 'Up here, you can see a crocodile as easily as it sees you', the saying goes, as far as the end of navigable water is concerned. This observation is helpful, since it is this cool, crystal clear and more rapidly flowing water in the upper reaches of the Piongo Lavata that is considered to have healing properties. Whether you are healthy or not, a swim is always recommended on the rare occasion when visits are made to this remote zone. 


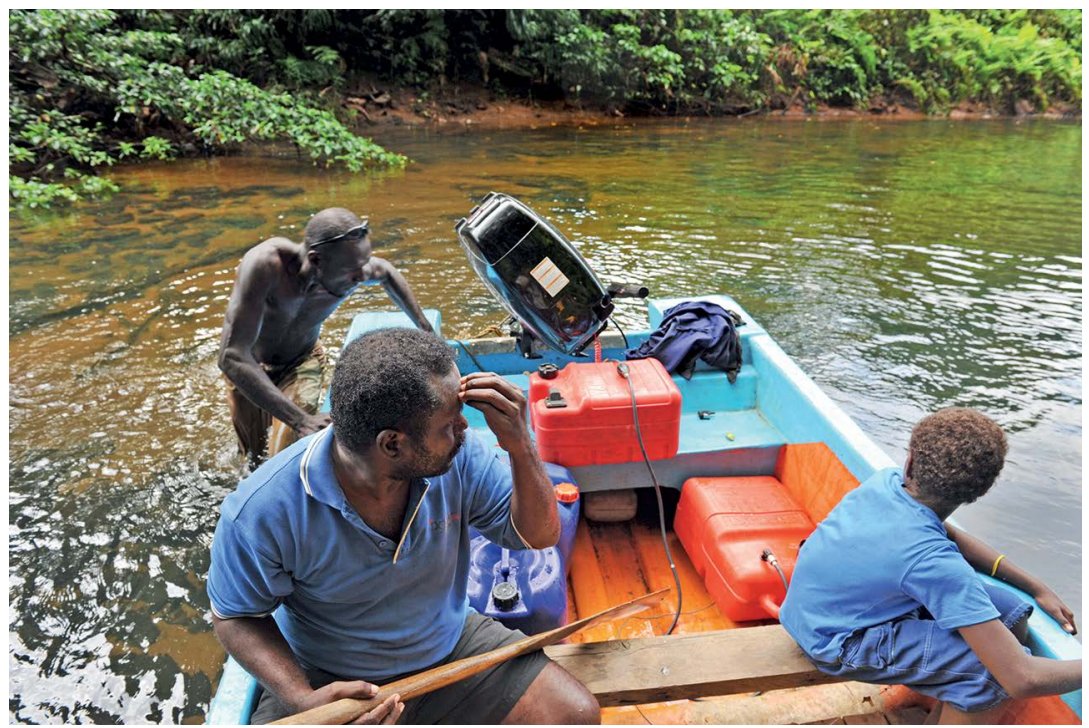

Figure 2.8 In the upper reaches of the Piongo Lavata River.

Source: Photo by the author, 2012.

Not far from the location shown in Figure 2.8, the Piongo Lavata narrows and rises quickly. Shallow water runs in rapids over boulders and, from this spot, water transport can only be obtained by first carrying small dugout canoes up through the rapids. However, $15 \mathrm{~km}$ from the coast as the pigeon flies, beyond the stony rapids and at an elevation of about $150 \mathrm{~m}$, the Piongo Lavata's headwaters are still not near. Fed by a multitude of tributaries that cascade down from the tall ridges of an old crater, the river meanders slowly for several kilometres, across a relatively flat upland basin where the water is fringed and partly hidden by dense tall forest not yet touched by logging machinery. Here, the Piongo Lavata forms wide, quite deep expanses of slow-moving water partly covered by the forest canopy. These are referred to as lakes (kopi, a term also applied to substantial reef basins out by the ocean), and have shorelines of volcanic boulders. No logging has taken place up here; the forest and the rivers are in pristine condition, and people very rarely go there. In fact, only a few men are likely to reach this far, in the course of hunting the feral pigs that are abundant near rivers in the upland forest-most people of New Georgia will never move this far inland. This remote place is also considered to be the home of a very special large animal, a somewhat mystical crocodile of the inner lands, considered locally to be a separate species. Past the spectacular upland river lakes are the proper headwaters 
of the Piongo Lavata. The great river has its beginnings on steep mountain ridges rising up to $400 \mathrm{~m}$ above sea level, with a singular vegetation of particular Pandanus, Casuarina and ginger species and mosses hanging from the branches of stunted trees, and with a specific repertoire of song from mountain birds.

The headwaters of most rivers of New Georgia emerge in such highelevation places from clusters of smooth volcanic boulders, from which small streams meet to form tributary rivers that ultimately converge in one major watercourse in valley bottoms. There is a distinct vocabulary concerning high-altitude headwaters, such as for describing the particular sounds made by clear water that flows forth and trickles over boulders and makes a river begin. Standing on a reasonably clear day among boulders and stunted high-altitude vegetation by the headwaters of a major river like the Piongo Lavata, at the end of what feels like a journey in both time and space, the traveller is likely to be amazed by the sweeping views over huge tracts of hill forest towards the remote lagoon and very distant barrier islands. In central New Georgia, such views can even cover both the Roviana and Marovo lagoons and, in clear weather, the other islands of the New Georgia archipelago are clearly seen, as well as the outlines on the northern horizon of the islands of Choiseul and Isabel. Following a big river to its beginnings demonstrates the scale of place in New Georgia; even for a Vahole person, who may only be up here once in a lifetime, the realisation of the extent of the ancestral land and of the scale of the landscape is particularly acute-the moment is an emotional one. For saltwater people, this is as far as one can get from the ordinary everyday world.

\section{Vua: Chief of the River}

The observable lives of crocodiles ( $\mathrm{vu} a$ ) in Marovo converge in several ways with the life of the river, as exemplified by the Piongo Lavata. The crocodile's prominence in Marovo cosmology and cultural history makes it the 'chief of the river' (bangara pa kavo), an adversary to so many human projects, which evades people by stealth until it strikes by ambush. While the bush people of old Marovo had the river as a primary focus of movement and food production, and their present-day descendants maintain an overall orientation to the land and often travel on and otherwise use its rivers, I have indicated how the freshwater environment is viewed by saltwater people with ambivalence, as an environment quite 
hostile to their preferred way of life. For them, rivers harbour dangerous creatures, most significantly the crocodile, which has rivers and estuaries as its main haunts. In the enduring cultural structures of New Georgia totemism that I have already briefly mentioned, the crocodile is considered to be ancestrally unrelated to saltwater people, who, for their part, consider the shark (in its previously described generic sense) to be their ancestral relation. From an outsider perspective, it would seem remarkable that an animal usually known to the world as the saltwater crocodile would be totemically associated with bush people, but such are the spatial and cosmological distinctions in the world of Marovo. The crocodile is first and foremost a creature of the river, and of the mangrove forests in estuaries and along mainland shores. While it may well be encountered at sea, at times even prowling the barrier reef slopes facing the ocean, maritime places are not regarded in Marovo as its proper habitat.

Fundamentally, then, crocodiles are associated with those groups of bush people who have a strong historical connection to rivers and estuaries, and sharks are associated with saltwater groups whose histories are primarily maritime. The structural symbolic scheme is that in which saltwater people are to bush people as the shark is to the crocodile.

As living beings with ancestral qualities attributed to them, sharks and crocodiles share certain attributes. Those who hold sharks or crocodiles as their ancestral spirits must not insult, injure, kill or eat them. They must not refer to a shark or crocodile as such when sighted, reflecting a panMarovo desire to distance these dangerous animals from humans, who must maintain a respectful relationship-including the naming tabooto safeguard against attack. Even today, any crocodile or shark sighted is referred to as 'something', its whereabouts indicated not with hands, but by a directional flicker of the eyes. A crocodile may be alternatively referred to as 'old man' (maroke). While crocodile-related bush people commonly claim that such properly respectful behaviour protects them against attacks from the animal, and saltwater people claim that similar attitudes and relationships to sharks protect them against shark attacks, such safeguards are less effective when the roles are reversed. Most documented shark attacks in Marovo over the years have in fact involved people from bush butubutu, who also dive and fish with spears, and thereby enter the realm of the saltwater people, but do not possess their totemic protection. Saltwater people, who travel and fish in places that used to be largely free of crocodiles, are increasingly experiencing threats from them. Today, crocodiles seek out village shores, where dogs 
are easy prey at night, and spear fishermen from saltwater villages have, on occasion, even encountered crocodiles along the ocean-facing reef walls. It is said that crocodiles are no longer afraid of humans, since no one now hunts them, and nothing inhibits the vua from ranging far outside its river domains.

While an assessment from surveys carried out in 1989, based on local knowledge and information from crocodile hunters, concluded that 'only a widely scattered remnant number of crocodiles remain [in the New Georgia Islands]' (Messel and King 1990: 47), this is no longer the case. During my fieldwork in Marovo Lagoon in 2010 and 2012, people commented that crocodile populations had bounced back rapidly and were now at the level of pre-colonial times, when there was no hunting of the reptiles and they were held in sensible reverence even by saltwater people, owing not least to the proverbial habit of large ones to float threateningly close to village shores at dusk (irongo pa veluvelu). An old man commented to me: 'Crocodiles were abundant here in the old days. But now they are just as numerous again, and no longer afraid of humans!'

It is reasonable to assume that saltwater crocodiles, whose diets are diverse and well covered by the abundance of animal life in the rivers, mangroves and reefs of the larger Pacific islands, were numerous and truly menacing for the early settlers in the Melanesian archipelagos and further afield. The reptiles also had a greater Pacific range in the past: a review of extensive pan-Pacific materials by Best (1988) points to the enduring impact of Pacific Islanders' historical relationships with crocodiles, exemplified by Māori and other Polynesian traditions of giant man-eating lizards and similar mythical creatures, which may constitute society's long-term memory of human-crocodile relations. ${ }^{2}$

In the late colonial era, crocodiles were extensively hunted and decimated throughout most of the Solomons and so came to represent less of a threat. When I first came to live in Marovo in 1986, crocodiles were encountered infrequently and were not regarded as much of a danger, as long as one kept away from places known to be their habitual hideaways. The local hunting of saltwater crocodiles in estuaries and swamps at night, with rifles, spears, torches and lamps, and sometimes with the assistance of dogs, had been an enduring, regular activity around New Georgia. Pursued by those brave or foolhardy enough, and preferably

2 See also Torgersen (this volume) on the lethal mo' $o$ of the Wailuku River in Hawai' $i$. 
without ancestral relations to the crocodile, this had its origins in visits by Australian hunters during the 1950s. Surprisingly, there are no accounts in Marovo of a local crocodile hunter ever being killed or injured by his prey, even if the dogs were not so lucky. The saltwater crocodile has the most valuable of all crocodile skins, and, from the 1960s into the 1980s, local hunters could make substantial money from the sale of skins to entrepreneurial middlemen. The end of hunting came in the late $1980 \mathrm{~s}$ when the implementation of global crocodile conservation measures cut short demand, and no skins seem to have been traded in the Solomons since around 1990, except for those obtained from a small number of farmed animals. Whereas the aforementioned surveys carried out at the time concluded that the crocodile population was verging on extinction, assessments by villagers were not that pessimistic and, while the ban on the export of crocodile skins has remained in force, local populations have been booming in many parts of the country.

Even the occasional defensive shooting of crocodiles taking up residence too close to villages stopped altogether from 2003. That year saw villagers throughout the Solomons surrender all firearms through large-scale national disarmament by the Australian-led Regional Assistance Mission to Solomon Islands (RAMSI), which entered the scene after armed conflict had ravaged parts of the country since 1998 (Moore 2004). No longer are shots fired at crocodiles, except in those rare and bizarre cases when armed RAMSI soldiers have been dispatched by air to the scene of a crocodile attack, where they are usually unable to find the guilty animal or, if one is indeed located, to actually hit it with their high-tech automatic weapons.

In New Georgia, women, whether paddling on the lagoon or working in riverside locations (such as those already described), and children, paddling to school or playing by the shore, have been victims of the majority of attacks from the growing crocodile population. Crocodiles seem adept at capsizing a small dugout canoe and grabbing the hapless paddler; it is believed that they are clever planners, able to observe patterns of regular travel and to devise an appropriate ambush strategy. Even some men engaged in underwater spear fishing at the barrier reef have been attacked, although these are considered unlucky chance encounters caused by increased crocodile mobility. Some victims have disappeared without a trace, the mangled, decomposed remains of a few have been retrieved, and some have escaped alive but with serious injury caused by the crocodile's 'death roll', a violent movement aiming at ripping large prey apart. 
Quite simply, people say that the crocodiles of Marovo have become fearless and ruthless. The predators have really honed the skills of stealth and ambush that they were prevented from developing so long as people shot at them and made them hide in the mangroves. Today, the vua is everywhere-in the upper and lower reaches of rivers, in mangroves, on village shores, in the lagoon and around the lagoon islands, and even in the barrier reef. Anyone who goes to the seaside at night for toilet needs (and nearly everyone still has to do so) must now bring a torch and watch out for whatever is lurking near the shore or under overhanging trees. In some villages, where children used to paddle to school in the morning in small dugout canoes, group transport by motorised boat is now the cautious strategy. On another level, it is increasingly claimed today that the crocodile no longer follows its prescribed behaviour according to the totemic contract with those butubutu with which it is associated, since even people from those groups are now being attacked. Some say the crocodile spirits are angered by the environmental destruction caused by logging. Some survivors of crocodile attacks belonging to crocodile-associated groups have told tales of a human-like spirit being hovering as an opaque shadow nearby while they were in the animal's jaws - a reference to the growing belief that sorcerers also take advantage of the present abundance of crocodiles.

'It is we humans who are now the endangered species', is a comment heard throughout Marovo in the twenty-first century, with a wry reference to the local human consequences of global conservation. Similar observations are made throughout the Solomons in places where rapid increases in crocodile attacks are experienced. On 26 July 2011, the news site Solomon Times Online carried this frank assessment from the government:

\section{Crocodile Population a Worry: Ramofafia}

The Solomon Islands Ministry of Fisheries says it will call an urgent meeting with the Ministry of Environment to discuss the country's growing crocodile population.

The crocodiles are an increasing threat to livelihoods and in some cases lives. The numbers of crocodiles in Solomon Islands started to increase after the trade in crocodile skin was banned in the early 1980s. The situation has become more challenging after the country became gun-free with the deployment of the Regional Assistance Mission in 2003. Dr Christian Ramofafia, Permanent Secretary of the Ministry of Fisheries and Marine Resources, acknowledges the problem and says they are doing all they can 
to address the problem. An accurate count of annual crocodile attacks on humans in the Solomon Islands is somewhat difficult to obtain. Many of the areas in which humans and large crocodiles come into contact are in remote parts of the Solomon Islands. Crocodile attacks are therefore not always reported to local authorities, and some reports are difficult to verify. (Anon. 2011)

\section{Flows, Directions and Inhabitants}

Despite the present overflow in terms of population and territory, the saltwater crocodile remains an icon first and foremost of New Georgia's rivers, being the most prominent and most dangerous inhabitant of this particular environmental domain. But there are also other creatures that approach such iconic roles, though not representing a danger to humans. The large freshwater eels are a case in point; their attractiveness as a particularly 'greasy' protein food and the singular methods of locating and catching them remain firmly in the domain of bush people. The mullet, on the other hand, which forms huge seasonal schools in the lower reaches of major rivers, is iconic for the river activities of saltwater people, who are the most adept in finding and netting those schools. While the mullet is viewed as a fish of the sea and a sought-after source of prestigious food, this is not so for the plethora of mainly small, truly freshwater fish. While some bush people are known for catching even the smallest freshwater fish for everyday food, most of them, and all saltwater people, consider freshwater fish to have a weak and watery taste, and to be food only for the elderly and sick or for pregnant women. Mangrove snapper, the only river fish of some size, is widely disliked and avoided as food because of its habit of eating snakes.

There are also other fishes known in areas of New Georgia to be characteristic inhabitants of certain waterways or of rivers in general. Some pointed out to me during fieldwork do not readily conform to existing scientific overviews of the freshwater fauna of the Solomon Islands. ${ }^{3}$ In general, the rivers of the Solomons are poorly studied by biologists, and new species are often found when surveys are done. After a rewarding trip to the island of Choiseul, across the sea from New Georgia, David Boseto (the only Solomon Islander freshwater biologist) and his research

3 A type of colourful smaller eel with a laterally flattened body and pointed snout, swimming in the clear middle reaches of Piongo Lavata, comes to mind. 
team concluded that '[ $\mathrm{t}$ ]he low freshwater fish diversity recorded for Pacific Island countries can, in some cases, be attributed to the absence of research being carried out' (Boseto et al. 2007: 16).

The rivers of New Georgia, then, are scenes for intense interaction among differentiated social groups and ecological domains and the living creatures there, which may be more or less well known to science. The river is always in motion, but so is the sea; every lagoon traveller takes into account a complex knowledge of currents and tides. But the river is unique in that it connects the land with the sea, differing from the land/sea connections made at the seashore and in the tidal zone. When there is high tide, the large rivers of New Georgia may have a surface layer of salt water several kilometres inland; conversely, at low tide, the brackish estuaries may be largely fresh some distance out into the lagoon along the mud flats. The river is seen by Marovo people as a unidirectional carrier of water, creatures, sediments and anything else from its terrestrial domain out into the sea, thus bringing the substance of mati into idere (see Figure 2.3). However, that is but one direction of the river's flow. The other is associated with human agency and involves travel from the coast towards inner lands, actively against the river's current (although a wise paddler in a small dugout canoe is not likely to try to reach far upriver when the tide is going out in the estuary). The constantly changing ebb and flow of the river, the massive stature of the riverside galleries of mangroves, nipa palm and tall rainforest, and the movement, both downriver and upriver, of non-human creatures and substances and human beings themselves all make for a world strikingly different from the sun-drenched openness of the lagoon seascape. In a cosmological scheme where that which is dark and cold is contrasted with conditions of light and warmth, navigating up one of New Georgia's rivers becomes a journey into the unpredictable and potentially antagonistic, especially for saltwater people. But even people whose historical connections are inland-of the bush-may take such views, considering the current universality of coastal village life on sunny lagoon shores.

I shall round off my account with a discussion of freshwater crocodiles, which, according to the received wisdom of biology, do not exist in the Solomon Islands. Biologists instead believe that the smaller crocodiles living in the upper freshwater reaches of rivers are simply young saltwater ones that seek refuge from voracious larger relatives. As noted by the foremost authority on the reptiles of the Solomons: 
Some popular travel guidebooks on the Solomons mention a second 'harmless' species of freshwater crocodile occurring in rivers. This is an incorrect and potentially dangerous piece of misinformation. There is only one species of crocodile in the Solomons, the saltwater crocodile, and even small specimens are far from harmless. (McCoy 2006: 16)

Nevertheless, in the vernacular conceptualisation of crocodiles in Marovo, two distinct species exist, and the notion of harmlessness is equivocal as far as the freshwater crocodile goes. I have noted that, while the saltwater crocodile or vua hokara ('proper crocodile') belongs to the realm of the bush people and is the close historical associate of many butubutu, it also leads a coastal existence and figures strongly in the traditions of a number of saltwater groups, who have no 'contract' with the vua that protects them from attacks. But saltwater people believe that another, much less common crocodile of true fresh water is capable of causing worse harm than the normal crocodile.

The usual story goes like this. If you venture far inland, up the major rivers into the upland basins where the water moves slowly in deep, calm meanders, as exemplified by the Piongo Lavata, you enter the territory of the vua varane ('warrior crocodile'). While the normal vua is known in Marovo to reach formidable sizes of $6 \mathrm{~m}$ or more, even while those of about 3-4 $\mathrm{m}$ are considered to be the most hungry and dangerous, the vua varane is usually only about a fathom long, with only a few approaching $3 \mathrm{~m}$ in total length. Unlike its broad-faced, heavy-set saltwater cousin, it has long narrow jaws and a nimble body, and it is faster and more aggressivehence its warrior label. Tales are told in the traditions of saltwater people about what could happen to raiding parties venturing upriver to take the heads of bush people. The vua varane could snatch warriors walking along a river bank and drag them away to be eaten. In an important sense, the vua varane - a true freshwater crocodile where, according to biology, there is none-stands for the dangers of the upper river and interior lands, in ways that reverse the time-honoured hierarchy in which saltwater people dominated bush people. If you are a saltwater man, you should only venture so far into a river as not to risk encountering the vua varane, which, unlike the bush people, has no fear of you. What, then, do bush people have to say about the vua varane? They claim to have no such animal-at least not one that is known by that name. True, they too insist that there are real freshwater crocodiles up there, with longish narrow jaws and nimble bodies, but their name for them is kapakale-a term that refers to their habit of resting on a stone or a submerged log. It is not 
regarded by them as dangerous, but they are well aware the saltwater men fear it. Like the environmentally malevolent transport of sediments into the lagoon, the mysterious freshwater crocodile is the river's triumph over the sea.

\section{Taming the Water: From River to Village}

Ideas of power, dominance, domestication and control, as exemplified above by the vua varane, are also at the core of some striking present-day reconfigurations. While I have discussed at length the environments and creatures of the river, and the role of the river in a cosmological scheme of relationships between land and sea, and the associated groups of people, in this final section I turn to a more direct engagement with rivers that takes on growing significance in twenty-first-century New Georgia. I move to a rural technological dimension, focusing on how a current efflorescence in New Georgia of quite advanced rural water supply systems is interpreted locally as a way of harnessing the forces of rivers for greater human comfort. And so I end my account with the more mundane aspects of fresh water in everyday village life.

Everyone in Marovo-except those who have access to rainwater tanks connected by gutters to corrugated iron roofs-depends on water from rivers, streams, springs and non-stagnant freshwater pools for drinking, cooking and washing. The high rainfall and massive network of natural watercourses offered by the rugged topography of New Georgia have made for relatively easy access to high-quality drinking water. But actually bringing the water to the houses has been more of a challenge.

Villages on the so-called 'weather coast' of the island of Vangunu are located near to sandy estuaries where large rivers enter the ocean. With the coastal land rising steeply just behind the narrow coastal plain, access to clean fresh water has always been easy in this part of New Georgia. For some coastal lagoon villages with a convenient location close to waterfalls, simple gravity-fed water supply systems, with a few standpipes distributed among the houses, had already been introduced in the 1980s. Stories were told around the lagoon of how those novel standpipes provided cool, clear water from waterfalls at pressures that could make a shower almost painful. This technological development, at first limited to a few fortunate villages, represented pioneering interventions into the river's flow of fresh water, which had until then been perceived by the majority of Marovo 
villagers as a resource subject to rather complicated access from sources far away from where they lived. Piped river water supplies, still gravityfed from somewhat higher altitudes, became widespread throughout Marovo during the 1990s, and effectively replaced labour-intensive and inefficient fresh water procurement. No longer was it necessary to walk to water sources, and no longer did entire villages have to depend on precarious springs or stagnant pools for fresh water. After the proliferation of standpipe systems in villages on the mainland shores of the Marovo Lagoon, the only remaining exceptions to the new rule of easy water access were the villages located on small waterless coral islands, where only those households with corrugated iron roofs could rely on rainwater tanks.

This ongoing improvement of village water supply throughout the Marovo area has reconfigured the enduring saltwater/bush distinction in significant ways. Whereas the lack of easily accessible fresh water used to be emblematic of the lives of saltwater people on small coral islands, the recent and present proliferation of innovative approaches to controlling and redirecting the flow of water for village purposes has now made abundant fresh water a fact of everyday life for almost everyone. New arrangements whereby saltwater villages on small islands off the mainland have obtained access to gravity-fed water supplies piped across the lagoon bottom from mainland rivers have, for example, involved significant rearrangements of gendered labour patterns. However, the cultural distinction between salt water and bush remains in place, since the expansion of piped water supplies to offshore islands has invoked new disputes over water ownership in cases where the recipients of the water do not own its source.

A striking example of technological innovation in mainland-offshore connections through fresh water, and consequent transformations of everyday life, comes from the barrier reef village of Keru in northern Marovo. Keru is located on a raised coral island with a jagged limestone topography, and, for many years, only had a seasonally fluctuating community water supply in the form of a rain-fed concrete tank whose contents were rarely fit for drinking. Visits to the mainland for laundry and bathing, mainly by the women of the village, used to involve up to 45 minutes of paddling each way, as well as hauling plastic cans of cool water from clean streams back to the village. Emblematic of the existence of true saltwater people, this had been the situation since Keru was settled around 1920, modified only slightly for a few households that obtained private rain-fed water tanks connected to corrugated iron roofs. 
By about 2000, when income from logging operations on the mainland foothills controlled by the Keru people allowed for it, ${ }^{4}$ an ambitious plan involving gravity-fed water from the upper reaches of a river was developed. From a small waterfall about a kilometre's distance uphill, a tough flexible pipe was led down to the seashore and made ready for the long reach, through many joined sections, across almost $5 \mathrm{~km}$ of lagoon out to Keru. Like Tamaneke, Keru is a village of the Christian Fellowship Church, an Indigenous religious organisation and powerful social movement that plays a significant political and economic role in New Georgia (Hviding 2011), and is also well known for its ability to mobilise massive communal labour. A notable feat of cooperation involving a number of villages of northern New Georgia saw several hundred canoes being paddled, on a fine calm day, into position to form a bridge-like structure between the mainland and Keru. Upon this platform of canoes, sections of concrete tubing were placed, through which the water pipe was led, in the process connecting every single canoe. At a given signal, all canoe crews pushed the concrete-and-pipe assemblage overboard onto the lagoon floor, which in some parts of this area is up to $20 \mathrm{~m}$ deep. Participants were somewhat surprised that not a single canoe capsized or sank at that moment. Symbolically, this was a spectacular feat of instantly connecting the river and the barrier reef, the fresh water and the sea, and the mainland territory of the Keru people with their offshore village. It was also about harnessing the water of the river to accomplish a major transformation of village life: no longer were those long hours of travel back and forth across the lagoon to mainland rivers necessary.

The construction of piped water supplies around Marovo, from the simplest to the most complex, is no mundane process in the eyes of its protagonists, but is interpreted as a process of 'domesticating' (va manavasa) the initially uncontrolled, 'wild' (piru) resource represented by relentlessly flowing river water. Whereas I have explained earlier how the flow of the river cross-cuts the wild and the domesticated, the water itself remains wild. In this sense, taming the wild water also engages another dimension of connectivity: bringing water to places of human habitation where there has not been any previously, thereby harnessing a power of the wild into a productive domesticated force that has the potential for completely transforming relationships of labour and gender in the village. Obviously, bringing river water under control for human purposes today echoes the

4 Despite their sea-oriented life, the people of Keru also control substantial forested lands. 
old times when the water of rivers and streams was diverted to feed the taro pond fields of the inland valleys. My discussion thus ends here, with an argument that embraces both connectivity and duality in the relationships of rivers and sea, of fresh and salt water-on a contemporary note where new forms of village-level technology are used to once more bring the forces of the river under human control. The river continues to flow-but its force may be converted into novel channels for human benefit.

\section{References}

Albert, S., M. Dunbabin, M. Skinner, B. Moore and A. Grinham, 2012. 'Benthic Shift in a Solomon Islands Lagoon: Corals to Cyanobacteria.' In Proceedings of the 12th International Coral Reef Symposium. Cairns: Australia.

Anon., 2011. 'Crocodile Population a Worry: Ramofafia.' Solomon Times Online, 26 July.

Balfour, A.B.F., n.d. 'Private Journal and Remarks 1893-1894-1895.' Balfour Collection 1873-1896 (ABA/V). London: Royal Geographical Society.

Bayliss-Smith, T. and E. Hviding, 2012. 'Irrigated Taro, Malaria and the Expansion of Chiefdoms: Ruta in New Georgia, Solomon Islands.' In M. Spriggs, D. Addison and P. Matthews (eds), Irrigated Cultivation of Colocasia Esculenta in the Indo-Pacific: Biological, Social and Historical Perspectives. Osaka: National Museum of Ethnology (Senri Ethnological Studies 78).

, 2015. 'Landesque Capital as an Alternative to Food Storage in Melanesia: Irrigated Taro Terraces in New Georgia, Solomon Islands.' Environmental Archaeology 20: 425-436. doi.org/10.1179/1749631414Y.0000000049

Bayliss-Smith, T., E. Hviding and T.C. Whitmore, 2003. 'Rainforest Composition and Histories of Human Disturbance in Solomon Islands.' Ambio 32: 346-352. doi.org/10.1579/0044-7447-32.5.346

Best, S., 1988. 'Here Be Dragons.' Journal of the Polynesian Society 97: 239-260.

Boseto, D., C. Morrison, P. Pikacha and T. Pitakia, 2007. 'Biodiversity and Conservation of Freshwater Fishes in Selected Rivers on Choiseul Island, Solomon Islands.' South Pacific Journal of Natural Science 3: 16-21. doi.org/ 10.1071/SP07003

Garson, J.G. and C.H. Read, 1892. Notes and Queries on Anthropology (2nd edition). London: The Anthropological Institute. 
Hviding, E., 1995. Vivinei Tuari Pa Ulusaghe: Stories and Legends from Marovo, New Georgia, in Four New Georgian Languages and with English Translations. Bergen: University of Bergen, Centre for Development Studies, in collaboration with Western Province Division of Culture.

—, 1996. Guardians of Marovo Lagoon: Practice, Place, and Politics in Maritime Melanesia. Honolulu: University of Hawai'i Press (Pacific Islands Monograph 14).

__, 2003a. 'Disentangling the Butubutu of New Georgia: Cognatic Kinship in Thought and Action.' In I. Hoëm and S. Roalkvam (eds), Oceanic Socialities and Cultural Forms: Ethnographies of Experience. New York: Berghahn Books.

— , 2003b. 'Contested Rainforests, NGOs and Projects of Desire in Solomon Islands.' International Social Science Journal 178: 439-453.

- 2005. Reef and Rainforest: An Environmental Encyclopedia of Marovo Lagoon, Solomon Islands / Kiladi Oro Vivineidi Ria Tingitonga Pa Idere Oro Pa Goana Pa Marovo. Paris: UNESCO (Knowledges of Nature 1).

- 2006. 'Knowing and Managing Biodiversity in the Pacific Islands: Challenges of Conservation in the Marovo Lagoon.' International Social Science Journal 187: 69-85.

_ 2011. 'Re-Placing the State in the Western Solomon Islands: The Political Rise of the Christian Fellowship Church.' In E. Hviding and K.M. Rio (eds), Made in Oceania: Social Movements, Cultural Heritage and the State in the Pacific. Wantage (UK): Sean Kingston Publishing.

Hviding, E. and T. Bayliss-Smith, 2000. Islands of Rainforest: Agroforestry, Logging and Ecotourism in Solomon Islands. Aldershot: Ashgate.

McCoy, M., 2006. Reptiles of the Solomon Islands. Sofia: Pensoft Publishers.

Messel, H. and F.W. King, 1990. 'The Status of Crocodylus Porosus in the Solomon Islands.' In Crocodiles: Proceedings of the 10th Working Meeting of the IUCNSSC Crocodile Specialist Group. Gland: IUCN.

Moore, C., 2004. Happy Isles in Crisis: The Historical Causes for a Failing State in Solomon Islands, 1998-2004. Canberra: Asia-Pacific Press.

Somerville, H.B.T., 1897. 'Ethnographical Notes in New Georgia, Solomon Islands.' Journal of the Royal Anthropological Institute 26: 357-413. doi.org/ $10.2307 / 2842009$ 
This text is taken from Island Rivers: Fresh Water and Place in Oceania, edited by John R. Wagner and Jerry K. Jacka, published 2018 by ANU Press, The Australian National University, Canberra, Australia.

doi.org/10.22459/IR.06.2018.02 